\title{
Entrepreneurial Attitude of Street Youth: In Case of Jigjiga Town, Somali Region, Ethiopia
}

\author{
Addisu Tesema Tanga \\ Lecturer Department of Management, College of Business and Economics, Wolaita Sodo University \\ P.o.box: 138, Wolaita Sodo, Ethiopia
}

\begin{abstract}
The general objective of the study is to assess the entrepreneurial attitude of street youth in Jigjiga town. In the study both primary and secondary source of data have been used. The total populations were 220 and based on Taro Yamane sample size determination formula; the study has used 142 samples from the total population. The study adopted simple random sampling technique to select the samples from the total population. In the study, 142 questionnaires were distributed for respondents and 136 has been properly filled and returned. The findings show that, lack of access to finance and absence of entrepreneurial skill were the key factors which affect the street youth from joining entrepreneurial world.
\end{abstract}

Keywords: Entrepreneurship, Street youth, Attitude, Jigjiga town

DOI: $10.7176 / \mathrm{EJBM} / 12-7-02$

Publication date: March $31^{\text {st }} 2020$

\section{Introduction}

\subsection{Back ground of the study}

The concept of entrepreneurship has been around for a very long period of time, but it is resurgent popularity implies a sudden discovery. As if we had stumbled on to a new direction for an enterprise (david.2003;-p-2- ). Development is more than ever linked to entrepreneurship. Institutions and Individuals promoting development now see entrepreneurship as a strategic Development intervention that could accelerate the development process. Furthermore institutions and individuals seem to agree on the urgent need to promote Entrepreneurship. Development agencies see entrepreneurship as an enormous Employment potential; politicians see it as the key strategy to prevent unrest; Farmers see it has an instrument for improving farm earnings; women see it as an employment possibility near their home which provides autonomy, independence and reduced need for social support. To all these groups however entrepreneurship stands as a vehicle to improve the quality of life for individual's families and communities and to sustain a healthy economy and environment. The entrepreneurial orientation to development accepts entrepreneurship as the central force of economic growth and development without it other factors of development will be wasted. However, the acceptance of entrepreneurship as a Central development force by itself would not lead to development and the advancement of enterprises. What is needed in addition is an enabling environment for successful entrepreneurship. The existence of such Environment largely depends on policies promoting entrepreneurship. It is important to bear in mind the entrepreneurial skills that will be needed to improve the quality of life for individuals, families and communities and sustain a healthy economy and environment. Taking this into consideration, it is better to explain some of the qualities or characteristics that are required/ expected on the part of entrepreneurs as explained in (Hayley,2007, p.27-32)

* Need for achievement:-according to McClelland, entrepreneurs have a higher need for achievement than do members of the general population.

* Willingness to take risks:-assuming some kind of risk is inherent in starting and running a business.

* Self-confidence: - entrepreneurs tend to be self-reliant individuals who see the problem in launching a new venture but believe in their own ability to overcome these problems.

\# Innovation: - innovation is at the very heart of entrepreneurship. It is a continuous purposeful search for new ideas and doing things differently.

\subsection{Statement of the Problem}

According to Hisrich et al. (2005), entrepreneurship is a dynamic process of creating incremental wealth in which the wealth is created by individuals who undertake the risks involved in terms of equity, time, and career. Entrepreneurship is a stepwise process that is influenced by both exogenous and endogenous factors, such as the existence of a business-friendly environment, the availability of the required factor endowments, the ability to acquire desired resources, and the ability to implement and manage the business concept (Mueller, 2008; Morris et al., 2001). According to previous research (Bandura, 1997; Carsrud et al., 1987), role models tend to be the basis for increasing entrepreneurial attitude or intention. However, this research should make an emphasis on the areas which are not been addressed by other researchers. 


\subsection{Research Questions}

The following key questions have been addressed by the study:

i. What factors affect the attitude of street youth towards entrepreneurship?

ii. What are the constraints that the street youth or young face in starting up a business?

iii. What inspires the street youth in starting and running their business?

iv. What issues improve the acceptance of entrepreneurship in youth society and among the street youth in particular?

\subsection{Objectives of the Study}

\subsubsection{General Objective of the Study}

The General objective of this study is to identify the attitudes of street youth on entrepreneurship and business orientation.

\subsubsection{Specific objective of the study}

* To identify the factors those affect the attitude of street youth towards entrepreneurship.

* To determine the constraints that the street youth face in starting up a business.

\# To evaluate motives of street youth's in starting and running their business.

\# To determine what factors improve the acceptance of entrepreneurship in youth society and among the street youth in particular.

\section{Review of Related Literature}

\subsection{Introduction}

Entrepreneurship and business creation are a growing alternative for young people whose age group often faces a labor market with double digit unemployment rates. Traditional career paths and opportunities are disappearing rapidly." (Ulrich Schoof,2006, p.1). A growing number of people are taking up challenge of starting their own business and much is being learned about how the odds for success can be improved through various types of assistance and through the creation of a supportive environment.

\subsection{Definition of Entrepreneurship and entrepreneur}

Entrepreneurship is the dynamic process of creating incremental wealth, the wealth is created by individual who assume the major risk intermesh of equity, time and career commitment or providing volume for some product or service (Ronstad, 1984.p.28). Entrepreneurship is the process of discovering, evaluating and exploiting opportunities which go on to verify them in the form of new business venture (Stevenson, 1986.p.28). Entrepreneur is a person who does entrepreneurial work within a large organization (Pinchot, 1983: p-512).

\subsection{Social and cultural attitude towards entrepreneurship}

As cultural and social backgrounds influence an individuals' approach to life, they similarly influence entrepreneurial activity and enterprise culture. (Gibb, 1988). Defined an Enterprise culture as "set of attitudes, values and beliefs operating within a particular community or environment that lead to both "enterprising" behavior and aspiration towards self-employment. "Researchers have long realized that cultural attitudes influence the entrepreneurial activities of a population, a country, region or ethnic group and that the interaction between culture and entrepreneurship is stronger in the case of some groups than others. Thus cultural differences between nations are increasingly understood as an important determinant of a nation's level of economic and entrepreneurial development. A cultural environment in which entrepreneurship is respected and valued, and in which business Failure is treated as a useful learning experience rather than a source of stigma, will generally be more conductive to entrepreneurship.

\subsection{The Social Legitimacy and Perception of Entrepreneurship}

Cultural values can have an important influence on entrepreneurial behavior. However, that does not imply that they are enough to cause or to inhibit the rise of entrepreneurial Activity. Social perceptions and perceived legitimacy of entrepreneurship are also an important factor in helping or hindering entrepreneurial behavior. According to (Welkin,1979). The degree of approval or disapproval of business activity will influence its emergence and characteristics, being favored by those environments in which entrepreneurs enjoy greater legitimacy. How individuals perceive entrepreneurship depends particularly upon:

i. Their personal environment (family, relatives, parents and friends).

ii. Their individual awareness and familiarity with the concept of entrepreneurship; and

iii. The general reputation, acceptance and credibility of entrepreneurs in society.

The following could be used to promote an entrepreneurial culture among people:

i. Research: Understanding cultural influences on entrepreneurship and assessing the attitude, awareness and aspirations of young people towards it. In order to promote an entrepreneurial culture among young 
people, it is crucial to know more about people's attitude, awareness and aspirations towards entrepreneurship and business.

ii. Promotion of role models Successful social or private, youth or adult entrepreneurs are probably the best ambassadors for promoting entrepreneurship among young people.

iii. Campaigns, competitions and awards, media coverage, youth business events Campaigns, events, competitions and awards are another way of raising the profile of entrepreneurship for people.

iv. Introduction and promotion of the entrepreneurial culture through education

\section{Research Design and Methodologies}

\subsection{Study Area}

Jigjiga is a city in the Somali Region of Ethiopia. It became the capital of the Somali Regional State in 1995 after it was moved from Godey. Located in the Fafan Zone with $60 \mathrm{~km}(37 \mathrm{mi})$ west of the border with Somalia, the city has an elevation of 1,609 meters above sea level.

\subsection{Research design}

The study focused on entrepreneurial attitude of street youth the case of Jigjiga town. In the study the descriptive design has been implemented because, it provided answers to questions like who, what, when, where and sometimes how. It enables respondents to give more information freely.

\subsection{Study population}

The Population is limited to the street youth of Jigjiga town, who are living currently in the street of the town and they are 220 and above in number

\subsection{Method of data collection}

The study has applied questionnaires to collect primary data from valuable sources (i.e. Jijiga town street youth). In addition, the study has used secondary data from published and unpublished sources.

\subsection{Sample techniques and sample size}

In this study, Simple random sampling technique has been implemented .This sampling technique is much useful to get true representative of the population, less expensive and the study has the advantages of an easy practice.

\subsection{Sample size}

The total populations who were available on town on time are 220 in number, based on Taro Yamane sample size determination formula. The study has used 142 samples from the total population and it has been determined by using this formula:

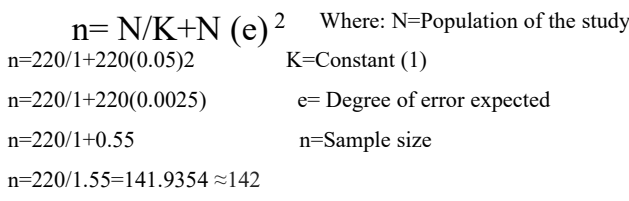

\subsection{Method of Data analysis}

The collected data has been analyzed and interpreted using descriptive statistical tools such as tabulation and percentage.

\section{Data presentation, Analysis and Interpretation}

This part discusses about the analysis, interpretation and findings of information collected from street youth of Jigjiga town. To collect the required data 142 questionnaires were distributed to street youth of Jigjiga town and 136 of them were collected back. 
Table 4.1: Demographic profile of the respondents

\begin{tabular}{|c|c|c|c|}
\hline S/No & Item & Frequency & Percentage \\
\hline \multirow[t]{5}{*}{1.} & \multicolumn{3}{|l|}{ Age } \\
\hline & $18-25$ & 112 & 82.35 \\
\hline & $26-40$ & 21 & 15.45 \\
\hline & $41-60$ & 3 & 2.20 \\
\hline & Above 60 & 0 & 0 \\
\hline \multicolumn{2}{|r|}{ Total } & 136 & 100 \\
\hline \multirow[t]{3}{*}{2.} & \multicolumn{3}{|l|}{ Gender } \\
\hline & Female & 41 & 30.15 \\
\hline & Male & 95 & 69.85 \\
\hline \multicolumn{2}{|r|}{ Total } & 136 & 100 \\
\hline \multirow[t]{4}{*}{3.} & \multicolumn{3}{|c|}{ Family Background } \\
\hline & Farmer & 4 & 2.94 \\
\hline & Employee & 42 & 30.88 \\
\hline & Business man & 90 & 66.18 \\
\hline \multicolumn{2}{|r|}{ Total } & 136 & 100 \\
\hline
\end{tabular}

Source: own survey

As depicted on Table 4.1, Majority of the respondents 112(82.35) are under 25 years of age. As a result most of the respondents are in their young ages. From this data we can conclude most of the street youth are young and middle age, this fact is good indicator that the majority of them are potentially productive work forces. On the other side the gender distribution of the respondents shows that $95(69.85 \%)$ of the respondents are male and the rest are female. This depict that the majority of the street you are males. As shown in the above table, 90 $(66.18 \%)$ of the respondents' family back ground is Business man, 42(30.88\%) of the respondent's families are employee of different organization and the rest of the respondents' families are from farmers. Family background seems to have an impact on entrepreneurial attitude and whether the street youth want to start a business or not.

Table 4.2: Problems for starting a business

\begin{tabular}{|c|c|c|c|}
\hline$S / N \underline{o}$ & Item & Frequency & Percentage \\
\hline \multirow[t]{3}{*}{1.} & \multicolumn{3}{|l|}{ Have you faced a problem of starting a business } \\
\hline & Yes & 128 & 94.12 \\
\hline & No & 8 & 5.88 \\
\hline \multicolumn{2}{|r|}{ Total } & 136 & 100 \\
\hline \multirow[t]{5}{*}{2.} & \multicolumn{3}{|l|}{ What is the problem you face to start the business? } \\
\hline & Financial & 92 & 67.65 \\
\hline & Ability and skill & 34 & 25 \\
\hline & Government regulation & 2 & 1.47 \\
\hline & Social/cultural attitude towards entrepreneurship & 8 & 5.88 \\
\hline & Total & 136 & 100 \\
\hline
\end{tabular}

\section{Source: own survey}

Table 4.2 depicted that the majority $128(94.12 \%)$ of street youth have faced a problem of starting business and most respondents $92(67.65 \%)$ and $34(25 \%)$, set as a reason is financial problem and lack of skill and ability respectively. From this we can conclude that young people are the actors in any activity and they have potential to create wealth and employment and ultimately provide the basis for economic progress. So serious obstacle to start up the business have the most critical constraints raised at different levels. Like; financial problems, lack of ability and skill, are the most problems that the street youth face.

Table 4.3: Business Experience and Interest Related Assessment

\begin{tabular}{|c|c|c|c|}
\hline S/No & Item & Frequency & Percentage \\
\hline \multirow[t]{3}{*}{$\overline{1 .}$} & \multicolumn{3}{|c|}{ Did you have any business experience of starting a business } \\
\hline & Yes & 14 & 10.29 \\
\hline & No & 122 & 89.71 \\
\hline \multicolumn{2}{|r|}{ Total } & 136 & 100 \\
\hline \multirow[t]{3}{*}{2.} & \multicolumn{3}{|c|}{ Do you have interest to start your own business? } \\
\hline & Yes & 124 & 91.18 \\
\hline & No & 12 & 8.82 \\
\hline & Total & 136 & 100 \\
\hline
\end{tabular}

Source: own survey 
Table 4.3 , shows that the majority $122(89.71 \%)$ of the respondents have no business experience and the remaining $14(10.29 \%)$ of the respondents have a business experience. This depict that most street youth are in need of training for business and entrepreneurial concept before they start their own business.

In addition the above table shows that, 124(91.18\%) of respondents want to start their own business and the rest $12(8.82 \%)$ of the respondents have no interest to start their own business and have no entrepreneurial attitude. This depicted that most respondents want to start their own business whereas; their interest has been generated from the individuals' attitude, role models and friends to start their own business.

Table 4.4: Reasons or motivations for starting up a business

\begin{tabular}{|c|l|l|l|}
\hline S/No & \multicolumn{1}{|c|}{ Item } & Frequency & Percentage \\
\hline \multirow{3}{*}{1.} & Starting business is the only chance to earn money for me. & 87 & 63.97 \\
\cline { 2 - 4 } & To be independent & 11 & 8.09 \\
\cline { 2 - 4 } & To help in creating employment & 8 & 5.88 \\
\cline { 2 - 4 } & To improve current living status & 30 & 22.06 \\
\hline \multicolumn{2}{|c|}{ Total } & 0 & 0 \\
\hline \multirow{2}{*}{ other } & $\mathbf{1 3 6}$ & $\mathbf{1 0 0}$ \\
\hline
\end{tabular}

\section{Source: own survey}

Table 4.4 , depicted that, the majority $87(63.97 \%$ ) of respondents' reason for starting business is to earn money, whereas the second largest respondents' reason is to improve their current living status. This shows, most street youth have good entrepreneurial attitude and they want to start business so as to earn money and withdraw them from street.

Table 4.5: Key Influencers to go in to Business and key de-motivators not to engage in Business for Street Youth

\begin{tabular}{|r|l|l|l|}
\hline S/No & \multicolumn{1}{|c|}{ Item } & \multicolumn{1}{c|}{ Frequency } & \multicolumn{1}{c|}{ Percentage } \\
\hline \multirow{8}{*}{1.} & Key influencers for street youth to start the Business \\
\cline { 2 - 4 } & Friends & 70 & 51.47 \\
\cline { 2 - 4 } & Entrepreneurs & 41 & 30.15 \\
\cline { 2 - 4 } & Media & 25 & 18.38 \\
\cline { 2 - 4 } & Family & 0 & 0 \\
\cline { 2 - 4 } & Religious leader & 0 & 0 \\
\cline { 2 - 4 } & Government & 0 & 0 \\
\cline { 2 - 4 } & other & 0 & 0 \\
\hline \multirow{2}{*}{2.} & key de-motivators for street youth not to start the Business \\
\cline { 2 - 4 } & Access to finance & 101 & 74.26 \\
\cline { 2 - 4 } & Lack of experience & 28 & 20.59 \\
\cline { 2 - 4 } & Fear of the work load & 0 & 0 \\
\cline { 2 - 4 } & Fear of lack of market demand & 2 & 1.47 \\
\cline { 2 - 4 } & Other & 5 & $\mathbf{1 0 0}$ \\
\hline
\end{tabular}

Source: own survey

All the respondents were asked to identify who can most influence their Opinions/attitudes about business either positively or negatively. Table 4.5 shows the summary of the responses of the street youth. About $70(51.47 \%)$ of the respondents claimed that friends can positively influence our attitude towards starting up a business. This depicted that friends have strong influence on street you attitude towards business. Based on the respondent's response, the other important point to note is that entrepreneurs are considered as key influencers and affect positively the attitude of street youth to start up a business. Accordingly, $41(30.15 \%$ of the street youth believe that entrepreneurs can influence the young students to start and run their own business. Thirdly, Media (Television, Radio, Magazines, and Newspapers etc.) is considered to have a very important role in influencing the street youth to consider starting up a business as important option to job creation or employment. Thus, from this it easy to conclude that, Friends, entrepreneurs, and Media are the key influencers that affect the attitude of street youth positively towards starting a business.

As can be seen from Table 4.5, the street youth were provided with statements related to the de-motivators for the street youth in starting up a business. Access to finance capital to invest is an important de-motivator according to the response from the street youth. It is considered by the majority $101(74.26 \%)$ of the respondents as the most common constraint limiting the pursuit of opportunities. On the other side, $28(20.59 \%)$ of the street youth side that, Lack of skills or lack of confidence in my skills and experience i.e., I am afraid of not having the right skills or experience. Accordingly, lack of finance and lack of required skills are considered as major demotivators for street youth that can make them not to join in business. 


\section{Conclusion and Recommendation}

\subsection{Conclusions}

This study has revealed about attitude of street youth on entrepreneurship. The respondents of the study were chosen from Jigjiga town. In the study 142 questionnaires were distributed for respondents and 136 has been properly filled and returned. The majority, $112(82.35 \%)$ of the respondents were below age of 25 and the ratio for gender distribution is also shows that the majority, $95(69.85 \%)$ of the respondents are male and the remaining are females. This study has shown that, family background has an influence on the street youth's future career, that is, whether they have to start their own business or pursue other jobs. This was clearly stated from the responses of Street youth whose family has been engaged in business tends/inclined to start their own business more than those whose family has different backgrounds. Most respondents replied that they would like to start their own business; the reason is to be independent or to be their own boss and starting up a business is the only chance to improve their living status.

As per the responses of the respondents, most of them replied that the reason that motivates them to start their own business is to be the need for independence.

That is they want to be their own bosses. On the other extreme, gaining recognition from the society was considered as the least important reason among the respondents. The major factors that hinders the starting of new business is lack of access to finance which was followed by lack of experience (i.e., education, training, business counseling and low level of understanding) towards the concepts of business ownership. According to the response of the respondents among the various influences that initiate Street youth to get into their own business, mostly Friends plays significant role. Media and entrepreneurs themselves plays still significant role. On the other hand, the most important de-motivating factors among the respondents were lack of access to finance to be invested. In addition, lack of entrepreneurial skill that de-motivates street youth from joining entrepreneurial world. The interview part depicted that, Most street youth strongly argue that most business people only run for their profit, that is, they do not care about the societies need or the feelings of the society. Again, significant number of street youth perceives business people as though they were engaged in malpractices. However, few street youth perceive that only very few business people are honest and conduct their business in a socially acceptable manner. Thus, one can conclude that, street youth's attitude towards business people is negative.

\subsection{Recommendations}

Based on the conclusions made the following recommendations are forwarded:

Promoting an entrepreneurial culture among people through: Understanding cultural influences on entrepreneurship and assessing the attitude, awareness and aspirations of people towards it.

\& Promotion of role models. Successful social or private, youth or adult entrepreneurship is probably the best ambassadors for promoting entrepreneurship among people. By delivering an image of independence, successes and achievement they can motivate people to consider and explore entrepreneurship and selfemployment. The more the people know successful entrepreneurs, the more likely he/she might become personally interested in starting a business because they have role models to follow. Moreover, when supported by media campaigns, credible models can have an influence on the street youth's Personal environment, so that parents and relatives will change their attitude towards entrepreneurship as well and encourage their children to engage in the field.

- Campaigns, events, competitions and awards are another way of raising the Profile of entrepreneurship for street youth. Business events can be useful Instruments for introducing entrepreneurship to youth. Moreover, they provide good opportunities for media exposure. Business competition and awards provide Special incentive for ambitious people.

Improving access to finance/facilitating debt financing for people/ improving the administrative and regulatory environment for debt finance. For example, this can be done by strengthening the micro finance institutions to provide start up capitals for the street youth living in area of Jigjiga town.

Developing and implementing entrepreneurship policies by concerned government agencies so as to provide Conducive environment for the street youth who are living in various area of Jigjiga town to consider starting up a business as one alternative to looking for employment. In Addition, governments should encourage the business starters by providing Subsidies of different types, for example, tax exemption in the early days of the Business, provision of working space free of lease, and the like.

$\rightarrow$ Offering practical short term trainings on entrepreneurship with the help of experts and successful entrepreneurs. Finally, the study believe that further researches need to be under taken on entrepreneurship to understand the subject matter very well and to come up with recommendations based on findings with a better scope/coverage. 


\section{References:}

[1] Beugelsdijk, S. and Noorderhaven,N. (2004) Entrepreneurial attitude and economic growth: A cross section of 54 regions. The Annals of Regional Science. 38(2), 199-218.

[2] Bhutta, M.K.S., Rana, A.I. and Asad, U. (2008) Owner characteristics and health of SMEs in Pakistan. Journal of Small Business and Enterprise Development. 15(1), 130149

[3] Boone, W. J. (1997). Science attitude of selected middle school students in China: A preliminary investigation of similarities and differences as a function of gender. School Science and Mathematics, 97, 96-103.

[4] Bygrave, W. and Miniti,M.(2000) The social dynamics of entrepreneurship. Entrepreneurship: Theory and practice, 24(1).

[5] Dionco-Adetayo, E.A.(2006). Factors influencing attitude of youth towards entrepreneurship. International Journal of Adolescence and Youth, 13(1-2), 12-145.

[6] Oyeniran, A.\& Alliyu, O.(2015).Determinants of eco entrepreneurial intention among students:a case study of university students in Ilorin and Malete. Ethiopian Journal of Environmental Studies \& Management 8(1):107-112.8(1):

[7] Pulka, B.M. \& Aminu,A. (2014).An Assessment of Factors Influencing Students' Attitude towards Entrepreneurship Education in Nigerian Universities.Journal of Social Sciences (COES\&RJJSS).Vo.3.No.4.

[8] Pulka, B. M., Rikwentishe, R., \& Ibrahim, B. (2014). An Evaluation of Students' Attitude towards Entrepreneurship in some Selected Universities in North East Nigeria.

[9] Robson,M. (2015).Determining Entrepreneurial Motivation of Undergraduate Students in Ethiopian Higher Learning Institutions: A Case of Haramaya University.Middle Eastern \& African Journal of Educational Research, Issue 14

[10] Samuel, Y.A, Ernest.K., and Awuah.J.B.(2013). An Assessment of Entrepreneurship Intention among Sunyani Polytechnic Marketing Students.International Review of Management and Marketing.Vol.3, No. 1.

[11] Schlaeger Ch and Koenig M (2014). Determinants of Entrepreneurial Intent: A Meta-Analytic Test and Integration of Competing Models. Entrepreneurship Theory and Practice, Vol. 38 (2): 291-332.

[12] Scott M., Twomey D (1988). The long-term supply of entrepreneurs: Students' career aspirations in relation to entrepreneurship. Journal of Small Business Management; 26:5-13.

[13] Sniehotta FF, Presseau J \& Aranjo-Soares V. Time to retire the theory of planned behavior. Health Psychology Review, Vol. 8: 1-7.

[14] Tkachev A and Kolvereid L (1999). Self-employment intentions among Russian students. Entrepreneurship and Regional Development; 11(3):269-280.

[15] Gibson, Shanan G., Patrick, Christopher, Harris, Michael \& Harris, Denisha. (2010).Investigating the entrepreneurial attitude of African Americans: A study of young adults. Journal of Small Business Institute ${ }^{\circledR}$ National Conference Proceeding, 34 (1)101-111

[16] Tsige, Gebremeskel. (2009). Entrepreneurial attitude and business success. JBAS (Journal of the British Astronomical Society), 1 (1), 70-9

[17] Douglas, E., (1999) Entrepreneurship as a career choice. Attitudes entrepreneurial intentions and utility maximizations, Frontiers of Entrepreneurship Research, Babson College, Wellesley, Massachusetts

[18] Francisco, L, Yi-wen, C (2006), Testing the entrepreneurial intention model on a two country sample, working paper 06/7, Department d'Economia de iEmpresa, Spain. 